\title{
Current approaches in identification and isolation of human renal cell carcinoma cancer stem cells
}

\author{
Mohammed I. Khan ${ }^{1 *}$, Anna M. Czarnecka ${ }^{1}$, Igor Helbrecht ${ }^{1}$, Ewa Bartnik², ${ }^{2,}$ Fei Lian ${ }^{4}$ and Cezary Szczylik ${ }^{1}$
}

\begin{abstract}
In recent years, cancer stem cells (CSCs)/tumor initiating cells (TICS) have been identified inside different tumors. However, currently used anti-cancer therapies are mostly directed against somatic tumor cells without targeting CSCs/TICs. CSCS/TICs also gain resistance to chemotherapies/radiotherapies. For the development of efficient treatment strategies, choosing the best method for isolation and characterization of CSCS/TICS is still debated among the scientific community. In this review, we summarize recent data concerning isolation techniques for CSCs using magnetic cell sorting and flow cytometry. The review focuses on the strategies for sample preparation during flow cytometric analysis, elaborating biomarkers such as CXCR4, CD105, and CD133. In addition, functional properties characteristic of CSCS/TICs using side population selection through Hoechst 33342 dye, aldehyde dehydrogenase 1, dye-cycle violet, and rhodamine 123 are also discussed. We also include a special focus on enriching CSCS/TICS using three-dimensional cell culture models such as agarose-agarose microbeads and sphere formation.
\end{abstract}

\section{Introduction}

The identification of adult cancer stem cells (CSCs) in cancerous tissues prompted researchers to understand their role in carcinogenesis. Some cancer cells are more potent than others because of malignancies that arise from either the mutation of normal stem cells or tumor cells that acquire stem cell-like characteristics. CSC theory suggests that these small populations of cells can reproduce and sustain cancer even after subsequent treatment, act more

\footnotetext{
* Correspondence: imrankhanbioinfo@gmail.com

1 Molecular Oncology Laboratory, Clinic of Oncology, Military Institute of Medicine, ul. Szaserów 128, 04-141 Warsaw, Poland

Full list of author information is available at the end of the article
}

like normal stem cells, and are able to self-renew. These specialized cells are termed CSCs or, more broadly, tumor initiating cells (TICs). Furthermore, research has shown that CSCs/TICs not only exhibit characteristics of normal stem cells, but also gain greater resistance to chemotherapies/radiotherapies. Isolation and further characterization of CSCs/TICs still hold vast mystery among the scientific community owing to a lack of specific stem cell markers. Another difficulty is in determining the methodology employed in isolating CSCs/TICs. In this review, we summarize recent data concerning CSCs/TICs cell isolation techniques and markers for human renal cell carcinoma (RCC).

\section{Stem cell surface markers in RCC}

CD105 is a receptor for transforming growth factor (TGF) located on cell surfaces and takes part in TGF- $\beta$ signaling by interacting with TGF- $\beta$ receptors I and/or II. CD105 is important for angiogenesis and is also a prominent marker for mesenchymal stem cells (MSCs) [1]. Bussolati et al. [2] first derived $\mathrm{CD} 105^{+}$cells, as TICs, from patient specimens after radical nephrectomy. Magnetically sorted $\mathrm{CD} 105^{+}$ cells from minced tissue were subjected to further stem cell characterization studies. The frequency of $\mathrm{CD} 105^{+}$cells in this study was $8.06 \pm 3.3 \%$ and the cells were able to induce tumors in all mice with injected $\mathrm{CD} 105^{+}$cells. These results were in agreement with the CSC/TIC hypothesis (Table 1). Moreover, cells with the CD105 marker had much stronger features of CSCs/TICs compared with cells without $\mathrm{CD} 105$. The presence of $\mathrm{CD}_{105^{+}}$cells has also been demonstrated in established RCC cell lines 786-O, SMKTR2, SMKTR3, 769-P, Caki-1, Caki-2, ACHN, and RCC-6 $[3,4]$. Isolated CD $105^{+}$cells were further examined for other human MSC markers using the BD Stemflow ${ }^{\text {ma }}$ hMSC analysis kit (BD Biosciences, Franklin Lakes, New Jersey, USA). These cells had increased expression of CD73 and CD90 markers and decreased expression of CD44 and CD146. After culturing for 5 days, however, re- 
Table 1 Comparison of methods for CSC/TIC isolation

\begin{tabular}{|c|c|c|c|c|c|}
\hline Putative markers examined & Isolation method & Cell selection method & Cell lines/specimens examined & Examined CSC/TIC criteria & Reference \\
\hline ABCG2, CD90, CD105, CD133, EpCAM & $\mathrm{ALDH} 1$ & Flow cytometry & Renal: $\mathrm{ACHN}, \mathrm{KRC} / \mathrm{Y}$ & $\begin{array}{l}\text { Sphere formation assay, drug sensitivity } \\
\text { assay, in-vivo tumorigenicity }\end{array}$ & $\begin{array}{l}\text { Ueda et al., } \\
2013[45]\end{array}$ \\
\hline Not examined & ALDH1 & Flow cytometry & $\begin{array}{l}\text { Ovary: AMOC-2, HUOA, } \\
\text { OVCAR-3, ES-2, RMG-1, TOV-21G }\end{array}$ & $\begin{array}{l}\text { Sphere formation assay, in-vivo } \\
\text { tumorigenicity, invasion assay }\end{array}$ & $\begin{array}{l}\text { Kuroda et al., } \\
2013[62]\end{array}$ \\
\hline$A B C B 1, A B C G 2, A B C C 1$ & Hoechst 33342 & Flow cytometry & $\begin{array}{l}\text { Renal: 769P, 786-O, OS-RC-2, } \\
\text { SN12C, SKRC39 }\end{array}$ & $\begin{array}{l}\text { Drug sensitivity assay, clone formation, } \\
\text { in-vivo tumorigenicity }\end{array}$ & $\begin{array}{l}\text { Huang et al., } \\
2013[47]\end{array}$ \\
\hline $\begin{array}{l}\text { Sox-2, POU5F1, Cdh1, Cdh2, Snai1, Snai2, } \\
\text { Twist1, Twist2 }\end{array}$ & Hoechst 33342 & Flow cytometry & $\begin{array}{l}\text { Renal: RENCA, ACHN, CAKI-1, } \\
\text { SMKT-R2, SMKT-R3 }\end{array}$ & In-vivo tumorigenicity & $\begin{array}{l}\text { Nishizawa et al., } \\
2012 \text { [23] }\end{array}$ \\
\hline CD3, CD4, CD8, CD24, CD44 & Rhodamine & Flow cytometry & Renal: 786-O & $\begin{array}{l}\text { Colony formation assay, radiation sensitivity } \\
\text { assay, in-vivo tumorigenicity }\end{array}$ & Lu et al., 2013 [21] \\
\hline $\begin{array}{l}\text { CD24, CD44, CD31, CD146, CD90, CD73, } \\
\text { CD29, CK7, CD133, Vimentin, Musashi, } \\
\text { Nanog, Pax2, Oct-4 }\end{array}$ & $\begin{array}{l}\text { CD105-based cell } \\
\text { selection }\end{array}$ & Magnetic-activated cell sorting & Renal carcinoma specimens & Sphere formation assay, in-vivo tumorigenicity & $\begin{array}{l}\text { Bussolati et al., } \\
2008[2]\end{array}$ \\
\hline $\begin{array}{l}\text { CD34, CD45, CD14, CD44, CD29, CD73, } \\
\text { CD105, Pax2, CD117, Cytokeratin, } \\
\text { Vimentin, E-cadherin }\end{array}$ & $\begin{array}{l}\text { CD133-based cell } \\
\text { selection }\end{array}$ & Magnetic-activated cell sorting & Renal carcinoma specimens & In-vivo tumorigenicity & Bruno et al., 2006 [8] \\
\hline $\begin{array}{l}\text { CD24, CD29, CD44, CD73, CD146, CXCR1, } \\
\text { CD34, CD90, CD105, CD133, ALDH1, } \\
\text { CD117, CXCR4, Nanog, POU5F1, Sox-2, } \\
\text { Cytokeratin, Vimentin }\end{array}$ & $\begin{array}{l}\text { CXCR4-based cell } \\
\text { selection }\end{array}$ & Flow cytometry & $\begin{array}{l}\text { Renal: RCC-26, RCC-53, } \\
\text { SK-RC-17 }\end{array}$ & $\begin{array}{l}\text { In-vivo tumorigenicity, sphere formation } \\
\text { assay, drug sensitivity assay }\end{array}$ & $\begin{array}{l}\text { Gassenmaier et al., } \\
2013 \text { [14] }\end{array}$ \\
\hline \multirow[t]{6}{*}{$\begin{array}{l}\text { CD44, CD24, Sca1, Oct-4, Wnt, } \\
\text { ABC white 2, } \beta \text {-Catenin, }\end{array}$} & \multirow[t]{6}{*}{$\begin{array}{l}\text { Encapsulation of } \\
\text { tumor colony }\end{array}$} & \multirow[t]{6}{*}{$\begin{array}{l}\text { Cell recovery from 3D culture } \\
\text { inside macrobeads }\end{array}$} & Renal: RENCA & \multirow[t]{6}{*}{ Not examined } & \multirow[t]{6}{*}{$\begin{array}{l}\text { Smith et al., } \\
2011[66]\end{array}$} \\
\hline & & & Breast: MMT, K12, MCF7 & & \\
\hline & & & Uterus: JEG-3 & & \\
\hline & & & Prostate: DU145 & & \\
\hline & & & Colon: HCT116 & & \\
\hline & & & Bladder: J82 & & \\
\hline Oct-4 & $\begin{array}{l}\text { Encapsulation of } \\
\text { tumor colony }\end{array}$ & $\begin{array}{l}\text { Cell recovery from 3D culture } \\
\text { inside macrobeads }\end{array}$ & Renal (mice): RENCA & $\begin{array}{l}\text { Chemotherapy sensitivity assay, in-vivo } \\
\text { tumorigenicity }\end{array}$ & $\begin{array}{l}\text { Gazda et al., } \\
2013 \text { [84] }\end{array}$ \\
\hline $\begin{array}{l}\text { CD133, CD34, CD24, CD14, CD105, } \\
\text { CD45, Oct-3/4, Nanog, Sox-2, E-cadherin, } \\
\text { VEGF R2/KDR/Flk1, HGC }\end{array}$ & $\begin{array}{l}\mathrm{CTR2} 2^{+} / \mathrm{CD} 133^{+} / \mathrm{CD}_{2} 4^{+} \\
\text {cell selection }\end{array}$ & Flow cytometry & cCRCC specimens & $\begin{array}{l}\text { In-vivo tumorigenicity, chemotherapy sensitivity } \\
\text { assay, cell cloning and differentiation assay }\end{array}$ & $\begin{array}{l}\text { Galleggiante et al., } \\
2014[9]\end{array}$ \\
\hline \multirow[t]{2}{*}{ Oct-3/4, Nanog, Pax-2 } & \multirow[t]{2}{*}{$\mathrm{ALDH} 1$} & \multirow[t]{2}{*}{ Flow cytometry } & Renal carcinoma specimens & \multirow[t]{2}{*}{$\begin{array}{l}\text { In-vivo tumorigenicity, sphere formation } \\
\text { assay, drug sensitivity assay }\end{array}$} & \multirow[t]{2}{*}{$\begin{array}{l}\text { Wang et al., } \\
2015 \text { [63] }\end{array}$} \\
\hline & & & Renal: ACHN, CAKI-2 & & \\
\hline
\end{tabular}

$\overline{A L D H}$ aldehyde dehydrogenase, $c C R C C$ clear cell renal cell carcinoma, CSC cancer stem cell, TIC tumor initiating cell, VEGF vascular endothelial growth factor 
analysis of isolated $\mathrm{CD} 105^{+}$cells showed that only one-half of the cells were able to maintain the CD105 antigen, suggesting that $\mathrm{CD} 105^{+}$cells are highly differentiating and transient in nature [4].

CD133, also called Prominin-1 or AC133, is a pentaspan transmembrane protein first identified in mouse neuroepithelial stem cells and later described in human hematopoietic stem cells $[5,6]$. The $\mathrm{CD}_{133^{+}}$cell population has been identified as resident renal progenitor cells in adult normal human kidney [7] and contributes to tumor vascularization and angiogenesis. Bruno et al. demonstrated a contributory role of $\mathrm{CD} 133^{+}$progenitor cells derived from human RCC in tumor vascularization [8]. $\mathrm{CD}_{133^{+}}$and $\mathrm{CD}_{133^{-}}$cells were magnetically sorted using the magnetic-activated cell sorting (MACS) system to evaluate in-vivo angiogenesis and tumorigenic potential. $\mathrm{CD}_{133^{+}}$or $\mathrm{CD}_{133^{-}}$cells were transplanted into SCID mice with or without cells from the K1 RCC cell line at different ratios (i.e., 1:100 for $\mathrm{CD} 133^{+} / \mathrm{K} 1$ cells, 100:1 for

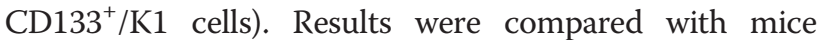
injected with $\mathrm{K} 1$ cells alone $\left(1 \times 10^{4}\right.$ to $1 \times 10^{6}$ cells $)$. Injected $\mathrm{CD}_{133^{+}}$cells alone did not form tumor after 6 months. However, $\mathrm{CD} 133^{+}$cells cotransplanted with the RCC cell line K1 significantly enhanced tumor growth and development. Moreover, newly formed vessels within the tumor were positive for both human HLA class I and human CD31, confirming its human origin. The fact that tumor vessels were derived from differentiating $\mathrm{CD} 133^{+}$ progenitor cells plus K1 cells was later confirmed by fluorescence in-situ hybridization for expression of human chromosome X [8]. Others have identified $\mathrm{CD} 133^{+}$cells that coexpressed CD24 and CTR2 antigens from RCC pa-

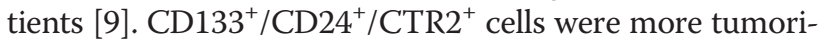
genic and have more potential to behave as CSCs/TICs compared with cells which do not express these markers.

CXCR4 chemokine receptor belongs to the superfamily of G protein-coupled receptors and has been found to be a prognostic marker in various types of human cancer. The chemokine CXCL12 (SDF-1) acts as a chemoattractant to the CXCR4 receptor-positive primary tumor cells, and drives them toward secondary metastatic sites. CXCL12-CXCR4 axis signaling is known to play a pivotal role in the homing of normal stem cells [10]. Interestingly, CSCs have been found to express CXCR4 receptor, and this CXCL12-CXCR4 axis is also involved in trafficking/metastasis of CSCs to the organs which are highly rich in CXCL12, such as the lymph nodes, lungs, liver, and bones [11, 12]. Schrader et al. analyzed the CXCL12/CXCR4 expression and function in four human RCC cell lines: A-498, Caki-1, Caki-2, and HA-7 [13]. Cell surface expression analysis of CXCR4 antigen using fluorescence-activated cell sorting (FACS) showed that only Caki-1 and A-498 cell lines expressed this antigen, which was also confirmed through RT-PCR.
Another breakthrough study [14] identified the pivotal role of CXCR4 receptor in maintaining cancer stem-like features and metastasis particularly in relation to RCC. The study examined two RCC lines, RCC-26 and RCC-53, derived from primary tumors of clear cell RCC (ccRCC) patients with disease stage I and IV, respectively. These differ significantly in their capability of forming tumor spheres. Under nonadherent conditions, RCC-56 cells form numerous spheres compared with RCC-26 cells, which form rather poor spheres. Flow cytometry analysis after dissociation of spheres demonstrated an increased fraction of $\mathrm{CXCR}^{+}$cells in a prosphere culture condition compared with a monolayer culture environment. In addition, sorted $\mathrm{CXCR}^{+}$cells from both cell lines have increased expression for stemness genes, such as Nanog, Oct-3/4, and Sox-2, and higher resistance to tyrosine kinase inhibitors, such as sunitinib, sorafenib, and pazapanib [14].

CD44 is a single-chain transmembrane glycoprotein that has a major role as an adhesion molecule for the extracellular matrix which binds primarily to the extracellular glycosaminoglycan hyaluronan $[15,16]$. CD44, a cell surface antigen, has been implicated in a wide variety of physiologic processes including wound healing, cell growth, survival, and differentiation as well as tumor cell migration, invasion, and metastasis. Some have also reported CD44 as CSCs/TICs [16, 17], although this nature is still controversial [18] (Table 2). Furthermore, clinical data have also suggested positive correlation between CD44 expression and metastasis [19]. Debeb et al. [20] described several features of $\mathrm{CD} 44^{+} / \mathrm{CD} 24^{-}$cells as CSCs/TICs which were derived from the human embryonic kidney cell line 293T. In-vivo observation of serially transplanted 293T cells showed self-renewal and sphere formation when cultured in a stem cell-promoting suspension culture. Moreover, CD $44^{+} / \mathrm{CD} 24^{-}$cells showed increased aldehyde dehydrogenase (ALDH) activity in three-dimensional culture compared with two-dimensional cell culture conditions. Furthermore, the three-dimensional spheres from $\mathrm{CD} 44^{+} \mathrm{CD} 24^{-}$cells were resistant to chemotherapy and radiotherapy [20]. These findings suggest the importance of $\mathrm{CD} 44^{+} \mathrm{CD} 24^{-}$cells as CSCs/TICs, but the underlying mechanisms are unclear. Similar results were also reported in Rh123 ${ }^{\text {high }}$ sorted cells and spheres from ccRCC cell lines 786-O, ACHN, and Caki-1 [21, 22] and in $\mathrm{CD}_{105^{+}}$cells isolated from RCC specimens [2].

\section{Intracellular markers in RCC}

Heat shock protein (HSP) 40 family member DnaJ (Hsp40) homolog, subfamily B, member 8 (DNAJB8) has an important role in maintaining the CIC/TIC phenotype in RCC and colon cancer [23, 24]. Overexpression of DNAJB8 enhances the expression of stem cell markers and tumorigenicity. The human RCC cell lines 
Table 2 Marker-based RCC CSC phenotypes

\begin{tabular}{|c|c|c|c|c|c|c|c|}
\hline Marker (positive) & $\begin{array}{l}\text { Sox, Oct, Nanog, } \\
\text { Bmi-1 }\end{array}$ & EMT markers $^{\mathrm{a}}$ & Spheres & Mice & Cell line & RCC type & Reference \\
\hline CD44, CD49f, ALDH1, CD24」 & + & $E \downarrow, M \uparrow+/-$ &,- ROS & + & Caki-1 & $\mathrm{CCRCC}$ & Mahalingaiah et al., 2015 [17] \\
\hline CD24, CD44 & + & $\mathrm{M} \uparrow$ & + & - & ACHN, Caki-1 & $\mathrm{pRCC}, \mathrm{cCRCC}$ & Lichner et al., 2014 [22] \\
\hline- & + & $E \downarrow, M \uparrow$ &,+ TNFa & - & $\mathrm{ACHN}, 786-0$ & $\mathrm{pRCC}, \mathrm{cCRCC}$ & Zhang et al., 2014 [27] \\
\hline $\mathrm{DCLK} 1 \uparrow \mathrm{ALDH} 1$ & + & $\mathrm{M} \uparrow$ & - & - & Caki-2 & $\mathrm{pRCC}$ & Weygant et al., 2015 [29] \\
\hline CD44, CD133, CXCR4 & NS, B-cathenin & $\mathrm{M} \uparrow$ &,+ PIK3R1 $\downarrow$ & - & $786-0, A-704$ & $\mathrm{CCRCC}, \mathrm{RCC}$ & Lin et al., 2015 [30] \\
\hline ALDH1 & + & - & - & + & Caki-2, ACHN & $\mathrm{pRCC}, \mathrm{pRCC}$ & Wang et al., 2015 [63] \\
\hline 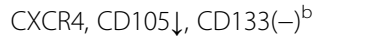 & + & - & + & + & RCC-26, RCC-53 & $\mathrm{RCC}$ & Gassenmaier et al., 2013 [14] \\
\hline CD24, CD44, CD133(-), CD105(-) & + & $\mathrm{B}-\mathrm{C} \uparrow$ & + & + & SK-RC-42 & $\mathrm{RCC}$ & Zhong et al., 2010 [72] \\
\hline CD24, CD44 & Side population & - & + & + & $786-0$ & $\mathrm{cCRCC}$ & Lu et al., 2013 [21] \\
\hline ALDH1 & - & NS & + & + & $\mathrm{ACHN}$ & $\mathrm{pRCC}$ & Ueda et al., 2013 [45] \\
\hline
\end{tabular}

${ }^{a}$ Mesenchymal (M): vimentin, N-cadherin, fibronectin, Snail, Fox-2, Slug, ZEB1. Epithelial (E): E-cadherin, cytokeratin, B-catenin

${ }^{\mathrm{b}} \mathrm{CD} 24, \mathrm{CD} 29, \mathrm{CD} 44, \mathrm{CD} 73, \mathrm{CD} 146$-highly expressed on cell line $=$ not considered as CSC markers

$\downarrow$ decrease, $\uparrow$ increase, $A L D H$ aldehyde dehydrogenase, $B$ - $c$ B-catenin, $C C R C C$ clear cell renal cell carcinoma, CSC cancer stem cell, EMT epithelial-mesenchymal

transition, NS not specified, $p R C C$ papillary renal cell carcinoma, $R C C$ renal cell carcinoma, $R O S$ reactive oxygen species, $T N F a$ tumor necrosis factor alpha

ACHN, Caki-1, SMKTR2, SMKTR3, and HEK293T together with murine RENCA cells and BALB/3 T3 cells from murine fibroblasts were analyzed for expression of DNAJB8 [23]. The ratio of side population (SP) cells derived from ACHN and RENCA cells was $2.6 \%$ and $18 \%$, respectively, using Hoechst 33342 dye staining. RT-PCR analysis of these isolated SP cells showed that $D N A J B 8$ was predominantly expressed together with Sox-2 and POU5F1 genes. Western blotting and immunostaining using SP cells also correspond with preferential expression of DNAJB8 protein, confirming stem cell-like phenotypes [23].

Micro RNAs (miRNAs) are small, noncoding, singlestranded RNA molecules that act as posttranscriptional regulators. They are required for the maintenance of normal pluripotent embryonic stem cells in mice [25]. The role of miRNAs has been documented in many cancers, including breast cancer, glioblastoma, and prostate cancer [26]. In RCC, Lichner et al. [22] examined the influence of miR-17 on cancer spheres with cancer stemlike properties from two metastatic RCC cell lines: ACHN and Caki-1. Spheres were obtained from ACHN and Caki-1 cells while cultured in serum-free defined media (SFDM) supplemented with fibroblast growth factor (FGF), epidermal growth factor (EGF), and B27. Sphere-forming cells were later examined for CD24 and CD44 CSC markers. Spheres from Caki-1 and ACHN cell lines were positive for $\mathrm{CD} 24^{+} / \mathrm{CD} 44^{+}$at $10 \%$ and $9.37 \%$, respectively. In addition, spheres from both cell lines exhibited greater tumorigenic ability and increased expression for stem cell and mesenchymal markers in vivo. However, miR-17 was significantly downregulated in both cell lines. Transfection with anti-miR-17 led to a rapid formation of three-dimensional spheres but did not affect the sphere-forming efficiency.
Interestingly, miR-17 inhibition resulted in 2.4-fold and 1.96-fold increase in the number of colonies formed in Caki-1 and ACHN, respectively, demonstrating capabilities of inducing self-renewal and significantly increased expression for mesenchymal markers such as ZEB1, ZEB2, vimentin, and $\mathrm{N}$-cadherin and for cancer stem markers CD24 and CD44 [22].

Emerging evidence suggests that acquisition of epithelial-mesenchymal transition (EMT) is associated with tumor invasion and metastasis. EMT plays an important role in tumor progression via an acquired ability to selfrenew, spread, and recur. Together, these features of EMT strongly suggest a possible relationship with the CSC phenotype. In a recent study, the EMT process was artificially induced inside the cell culture of RCC cell lines $\mathrm{ACHN}$ and 786-O to enrich their stemness features [27]. ACHN and 786-O cells were treated with $50 \mathrm{ng} / \mathrm{ml}$ tumor necrosis factor alpha for 7 and 14 days, respectively. This led to a loss of epithelial morphology and acquired mesenchymal appearance, and increased expression of mesenchymal protein markers such as Vimentin, Slug, and ZEB1. In addition, these EMT signature RCC cells had upregulation of stemness genes such as Oct-4, Nanog, and Bmi-1, together with increased potential of tumor sphere formation [27].

In contrast to artificially induced EMT, Li et al. [28] applied a different approach which can reverse the EMT process and inhibit CSC-like characteristics in RCC. Honokiol extracts isolated from Magnolia spp. bark can suppress the proliferation of RCC cells in vitro. Furthermore, there can be an increase in protein expression of epithelial markers E-cadherin and decrease in expression of mesenchymal markers such as fibronectin and Vimentin. Honokiol significantly decreases the number and size of tumor sphere formation and decreases the 
number of SP cells. All of these findings suggest that honokiol regulates EMT and CSC/TIC properties by modulation of miR-141 and its target gene ZEB2 [28].

Analysis of The Cancer Genome Atlas' Kidney Renal Clear Cell Carcinoma (TCGA KIRC) dataset revealed that Doublecontin-like kinase 1 (DCLK1) is epigenetically overexpressed in RCC tumors regardless of the disease stage [29]. Recently, Weygant et al. [29] investigated the importance of DCLK1 in regulation of EMT and maintaining stemness features. Silencing of the DCLK1 gene using DCKL1 small interfering RNA (siRNA) in primary RCC-caki-2 cells resulted in decreased expression of EMT transcriptional factors (SNAI1, SNAI2, TWIST1, ZEB1, and Vimentin). Moreover, this gene silencing also led to reduced expression of stemness and pluripotency factors MYC, Nanog, Oct-4, Sox-2, and ALDH1A1. These results illustrate the vital role of DCLK1 knockdown in reducing the invasive and metastatic capability of RCC. High protein expression of PIK3R1 has been observed in normal kidney tissues. Recent findings showed that PIK3R1 expression correlated with RCC progression and metastasis [30]. Functional study of PIK3R1 knockout revealed its significant role in RCC cell migration and proliferation [30]. Moreover, knockout PIK3R1 cells displayed a mesenchymal morphology and increased expression for EMTrelated factors in vitro.

\section{Multiple marker phenotype of RCC CSCs}

Coexpression of multiple putative stem markers in identifying CSCs has been studied in many cancers [31, 32]. Recently, Galleggiante et al. [9] identified cancer stemlike cells using the multiple marker $\mathrm{CTR}^{+} / \mathrm{CD} 133$ ${ }^{+} / \mathrm{CD} 24^{+}$from patients with clear RCC. This resident subpopulation showed stemness properties similar to tubular adult renal progenitor cells (tAPCs) derived from healthy kidney. $\mathrm{CD} 133^{+} / \mathrm{CD} 24^{+}$cells isolated from tumor kidney tissue were more undifferentiated than tAPCs. CTR2 is localized on the cell surface membrane and coexpressed with $\mathrm{CD} 133^{+} / \mathrm{CD} 24^{+}$cells. Expression of CTR2 has been reported by others in human RCC. Coexpression of CTR2 with CD133/CD24 protein could be useful in discriminating between CSCs and the normal renal cell population [9]. Moreover, in RCC patients a significant role of CTR2 in cisplatin-based resistance also been reported. Another example of a coexpression approach is to identify CSCs in RCC using CD133/ CXCR4-based cell selection. Resistance to sunitinib is a major obstacle in RCC treatment [33]. Varna et al. [34] studied the role of $\mathrm{CD}_{133^{+}} / \mathrm{CXCR} 4^{+}$cells in the course of developing such resistance. RCC specimens obtained from patients before and after sunitinib treatment were analyzed for cells expressing CD133. CD133-expressing cells were significantly more numerous in sunitinibtreated patients than in untreated patients. Interestingly,
$\mathrm{CD}_{133^{+}}$cells coexpressed CXCR4, which showed higher tumorigenic potential in vitro [34].

\section{Methods for the isolation of cancer stem-like cells Cluster of differentiation identification}

Another well-known method for stem cell separation is MACS. This widely used method isolates different types of cells including human lymphocytes, dendritic cells, mega-karyotic cells, and granulocytes [35-38]. The use of small magnetic beads conjugated with antibodies allows for direct enrichment and isolation of cells without further staining. Bussolati et al. [2] used this method to isolate tumor-initiating cells in specimens from RCC obtained after radical nephrectomy. Specimens were minced and digested using collagenase II. They used CD105 (endoglin) antibody conjugated with magnetic beads that recognized surface antigens for $\mathrm{CD} 105^{+}$ cells. Before isolation, $2 \times 10^{7}$ cells were initially labeled using $80 \mu \mathrm{l}$ monoclonal anti-CD105 antibody coupled with magnetic beads in cold MACS running buffer (phosphate-buffered saline (PBS) without $\mathrm{Ca}^{2+}$ and $\mathrm{Mg}^{2+}$ supplemented with $1 \%$ bovine serum albumin (BSA) and $5 \mathrm{mM}$ ethylenediamine tetraacetic acid (EDTA)) for $20 \mathrm{~min}$. Later, cells were washed twice using MACS buffer and were suspended in MACS buffer. The cell suspension was passed through a MACS magnetic column held on the MACs separator stand. During this process, CD $105^{+}$-labeled cells are collected inside the MACS column and can be further collected by pushing a plunger into the column [2].

\section{Side population isolation}

One of the most popular and commonly used methods to identify CSCs/TICs is SP cell selection using Hoechst 33342 dye [39-41]. The SP phenotype is a manifestation of primitive cells' ability to efficiently efflux the fluorescent DNA-staining dye (i.e., Hoechst 33342) and can be used to isolate these cells using flow cytometry [42]. This is in contrast to the protein marker approach for isolation, where cells are first immunostained with fluorescently conjugated antibodies. Later, positively fluorescent labeled cells are sorted using flow cytometry whereas the Hoechst 33342 dye efflux assay isolates cells based on the ability of stem cells to actively efflux cytotoxic agents like Hoechst 33342, a bis-benzimidazole that binds to adeninethymine-rich regions of the minor groove of DNA. SP cells have been analyzed by this technique from healthy hematopoietic stem cells inside bone marrow [43]. Moreover, this study showed that the SP also has exceptionally strong features of stem cell-like activities. There are many reports that suggest a role for CSCs/TICs in solid tumors, but only few reports contribute toward involvement of SP cells in RCC [23, 44-46]. 
Hoechst 33342 DNA binding dye (SIGMA-Aldrich, Saint Louis, USA) was used in two RCC cell lines derived from primary lesions of Japanese females (KRC/Y) and from malignant (ACHN) pleural effusion from Caucasian males with metastatic RCC [45]. Cells were cultured in monolayers until they reached nearly $80 \%$ confluence, and then cells were harvested using accutase and suspended at a density of $1 \times 10^{6} / \mathrm{ml}$ in PBS with $2 \%$ fetal bovine serum (FBS). Suspended cells were incubated with Hoechst 33342 dye at $37{ }^{\circ} \mathrm{C}$ for $60 \mathrm{~min}$. The samples were washed, centrifuged, and resuspended in $2 \mathrm{ml}$ cold PBS with $2 \%$ FBS. Propidium iodide (PI) was then added at a concentration of $1 \mathrm{mg} / \mathrm{ml}$ to measure dead cells. Cells were filtered through a $40 \mu \mathrm{m}$ membrane. Finally, the SP cell analysis was carried out through a FACS AriaII flow cytometer (BD Biosciences, San Jose, CA, USA). The SP percentage in ACHN and $\mathrm{KRC} / \mathrm{Y}$ cells was $1.4 \%$ and $1.7 \%$, respectively, whereas upon treating cells with reserpine no SP cells were observed. Hoechst 33342 dye staining was used for analysis of SP cells and non-SP cells in five established human RCC cell lines: 769P, 786-O, OS-RC-2, SN12C, and SKRC39 [47]. This method proved effective only in the 769P cell line; in the other cell lines, the ratio of SP cells was either too low or nondetectable. In addition, the expression of the ATP-binding cassette $(\mathrm{ABC})$ transporter $A B C B 1$, a member of the MDR/TAP protein subfamily, was higher in SP cells compared with non-SP cells, which was further confirmed by RT-PCR and western blot [47].

The ability to recognize Hoechst-positive SP cells depends on the differential efflux of cells by multidrug-like transporter protein. Great attention is therefore required for Hoechst concentration, staining time, and staining temperature. All steps are critical before analysis. In the RCC cell line 769-P, SP analysis and cell isolation was performed with a small modification as described previously by Goodell et al. [43]. The cells were mobilized using trypsin instead of accutase, and were suspended in prewarmed RPMI- 1640 containing $2 \% \mathrm{FBS}$ and $10 \mathrm{mmol} / \mathrm{l}$ HEPES [23]. RCC cells were spun down and resuspended at $1 \times 10^{6}$ cells $/ \mathrm{ml}$ in RPMI-1640, followed by standard incubation with $5 \mathrm{mg} / \mathrm{ml}$ Hoechst 33342 dye at $37{ }^{\circ} \mathrm{C}$ for $90 \mathrm{~min}$ in the dark. After staining, cells were spun down and resuspended in cold HBSS again containing $2 \%$ FBS and $10 \mathrm{mmol} / \mathrm{l} \mathrm{HEPES}$ for flow cytometry analysis. Another option is to suspend cells in prewarmed Dulbecco's modified Eagle's medium (DMEM) with 5 \% FBS. Hoechst 33342 dye can be added at a final concentration of $2.5 \mathrm{mg} / \mathrm{ml}$ in the presence or absence of verapamil $(50 \mathrm{mmol} / \mathrm{l})$. The cells may then be incubated at $37^{\circ} \mathrm{C}$ for 90 min with intermittent blending [23].

Hughes et al. [48] also employed the Hoechst SP approach for stem cell identification from renal epithelial cells and a novel method to further characterize SP cells using synchrotron radiation-Fourier transform infrared (SR-FTIR) spectroscopy. In this method, renal epithelial cells were first stained with Hoechst 33342 dye and sorted using a FACS vantage cytometer to define the SP gate. Thereafter, SR-FTIR spectroscopy was used to acquire single-point spectra and biochemical maps for each cell type. SP sorted cells were very small, consisting of a nucleus and limited cytoplasm, demonstrating that these cells have a distinct chemical phenotype compared with the remaining renal cells [48].

Another CSC identification method is based on the cells' ability to efflux toxins using rhodamine 123 (Rh123), which preferentially accumulates in active mitochondria. The content of Rh123 dye in the cells helps to isolate cells with progenitor characteristics $[49,50]$. Rh123 is a cellpermeable fluorescent dye that stains mitochondria in cells, since there is a correlation between the amount of ATP in cells, the fluorescence intensity of Rh123 dye, and drug resistance though the $\mathrm{ABC}[51,52]$. In the human $\mathrm{RCC}$ line 786-O, two different fractions of cells were observed: Rh123 ${ }^{\text {high }}$ cells and Rh123 ${ }^{\text {low }}$ cells. The $786-\mathrm{O}$ cell line was first grown in RPMI-1640 media supplemented with $10 \%$ heat-inactivated FBS using normal incubation conditions [21]. Once the cells reached a logarithmic growth phase, they were harvested using $0.25 \%$ trypsin. Cells were washed twice with calcium/magnesium-free PBS and resuspended in ice-cold RPMI-1640 with $5 \%$ FBS at a concentration of $1 \times 10^{6}$ cells $/ \mathrm{ml}$ and incubated for $10 \mathrm{~min}$ at $37{ }^{\circ} \mathrm{C}$ in $5 \% \mathrm{CO}_{2}$. Rh123 fluorescent dye was added at a concentration of $10 \mu \mathrm{g} / \mathrm{ml}$ and incubated for $20 \mathrm{~min}$ in the dark. Cells were washed twice with PBS and examined by flow cytometry. Sorted cells were divided into two groups: rhodamine high active cells (Rh123 ${ }^{\text {high }}$ ) and rhodamine low active cells (Rh123 $\left.{ }^{\text {low }}\right)$. Rh $123^{\text {high }}$ has been further assessed for other stem cell-like properties, such as colony formation, radio-sensitivity, screening for stem cell markers (CD24 and CD44), and tumor formation in SCID mice. The human primary RCC line 786-O was used to isolate the CSC/TIC population based on the Rh123 fluorescent intensity [21]. The cells with increasing intensity for Rh123 dye exhibit characteristics of stem-like cells that include higher colony formation capability, higher differentiation potential, and resistance to radiation and tumor formation in NOD/SCID mice [21].

CSCs/TICs are hypothesized to be resistant from toxins, hypoxia, and radiation $[53,54]$. One possible mechanism behind toxin efflux is through the expression of $A B C$ transporter proteins. Moreover, protein overexpression of members of the $A B C$ transporter superfamily ( $A B C B 1$, $A B C C 1$, and $A B C G 2)$ contributes to drug resistance and exhibits the SP phenotype. Hence, another method to isolate CSCs/TICs is based on the ability to efflux toxins using the dye-cycle violet (DCV) cell staining procedure. 
Recent studies have shown efficacy of this membranepermeable dye in identifying the SP in bone marrow and cultured cell lines of prostate cancer $[51,55,56]$. However, the role of DCV in CSC identification in RCC is still untested and not enough data have been reported. DVC is an alternative to Hoechst 33342 dye staining and is also a substrate for the ABCG2 efflux transporter protein that can be excited by a violet laser. Samples were prepared in suspension and Fumitremorgin C (FTC) was used to inhibit ABCG2 function to facilitate localization of DVC effluxing cells in prostate cancer [56, 57]. In darkness, $1 \mu \mathrm{l}$ DVC was added to $1 \times 10^{6}$ cells in $0.5 \mathrm{ml}$ epithelial culture media with or without $0.5 \mu \mathrm{l} \mathrm{FTC} \mathrm{[56].} \mathrm{Sample} \mathrm{tubes} \mathrm{were}$ vortexed and incubated at $37^{\circ} \mathrm{C}$ for $20 \mathrm{~min}$. After $20 \mathrm{~min}$, samples were vortexed and $1 \mu \mathrm{l}$ DVC was added again to obtain a final concentration of $10 \mu \mathrm{M}$. Samples were again incubated at $37{ }^{\circ} \mathrm{C}$ for $90 \mathrm{~min}$ and vortexed every $15-20$ min during incubation. Later, samples were centrifuged at $800 \times g$ for 5 min at $4{ }^{\circ} \mathrm{C}$ and washed with $1 \times$ PBS before resuspension in $0.5 \mathrm{ml}$ Hanks solution with $5 \%$ FBS buffer. Finally, $5 \mu \mathrm{l}$ of 7-aminoactinomycin D (7AAD) was added to the samples in the dark. Cells were sorted using FACS [56].

\section{Aldehyde dehydrogenase identification}

ALDH1 is an enzymatic approach for both normal stem cell and CSC/TIC identification. Researchers have used the ALDEFLUOR assay where high expression of ALDH1 enzyme activity corresponds to CSC/TIC markers in different types of cancer, including lung cancer, prostate cancer, breast cancer, bladder cancer, liver cancer, ovarian cancer, and malignant melanoma [58-63]. Ueda et al. [45] researched the biological features of ALDH1 $1^{+}$and ALDH1

in samples prepared from SP and non-SP cells, drugtreated cells, and cells cultured under hypoxic conditions previously isolated from two RCC cell lines. SP and nonSP cells were cultured for $72 \mathrm{~h}$. Later, samples were suspended in ALDEFLUOR assay buffer containing ALDH substrate with $50 \mathrm{mg}$ dry bodipy-aminoacetaldehyde, with or without $5 \mu \mathrm{l}$ ALDH inhibitor (diethylaminobenzaldehyde) as a negative control. Samples were incubated for $60 \mathrm{~min}$ at $37{ }^{\circ} \mathrm{C}$ inside the incubator prior to analysis using flow cytometry. An almost twofold increase of $\mathrm{ALDH}^{+}{ }^{+}$cells was observed in the metastatic ACHN cell line $(15.3 \%)$ compared with the primary $\mathrm{KRC} / \mathrm{Y}$ cell line (6.5\%). This research demonstrated that the number of $\mathrm{ALDH1}^{+}$SP cells $(32.7 \%)$ was double that of non-SP cells $(14.6 \%)$. In addition, the sphere-forming ability of ALDH ${ }^{+}$ cells was higher in both RCC cell lines compared with $\mathrm{ALDH}^{-}$cells and RCC cells were capable of forming tumors in mice [45].

\section{Three-dimensional cell culture}

The three-dimensional culturing of tumor cells can be used to closely mimic the in-vivo tumor microenvironment, unlike the traditional two-dimensional monolayer culture [64]. This novel three-dimensional culturing model for tumor cells in polymeric scaffolds was first discussed by Jain et al. [65]. In RCC, this method was employed to enrich the cancer stem-like cells from the mouse renal adenocarcinoma RENCA cell line using macrobeads [66]. RENCA cells were grown for 5 days inside six-well plates at a density of 15,000 cells per well containing $10 \%$ neonatal calf serum (NCS) in RPMI-1640 media. Separately, $100 \mu \mathrm{l}$ of $0.8 \%$ low-viscosity agarose was prepared in minimum essential medium (MEM), and kept at $51-53{ }^{\circ} \mathrm{C}$ followed by mixing with $1.5 \times 10^{5}$ RENCA cells. The agarose cell suspension was expelled into sterile mineral oil at room temperature to form a smooth, semi-solid core of macrobeads. Mineral oils were removed with RPMI-1640 and the core was cultured overnight at $37^{\circ} \mathrm{C}$ under $5 \%$ $\mathrm{CO}_{2}$. The following day, the core was rolled in a sterile spoon containing $1 \mathrm{ml}$ of $4.5 \%$ agarose in MEM maintained at $61-63{ }^{\circ} \mathrm{C}$ to apply an outer coating of agarose. These agarose-agarose macrobeads were transferred to mineral oil to form smooth macrobeads and washed again with RPMI-1640 prior to culture. Macrobeads were cultured at $37{ }^{\circ} \mathrm{C}$ in $5 \% \mathrm{CO}_{2}$ in a $90-\mathrm{mm}$ Petri dish containing 10 macrobeads in $40 \mathrm{ml}$ of $10 \%$ NCSsupplemented RPMI-1640 media. Immunofluorescence studies on RENCA macrobeads show enrichment of CSC/progenitor cell-like attributes [66]. These cells tested positive for CD44 (CD24-), stem cell antigen-1 (SCA-1), and OCT4 protein.

Culturing conditions for $\mathrm{CD} 105^{+}$clones to grow as a floating tumor sphere were first modified by Bussolati et al. [2]. Cells were plated at $1 \times 10^{3}$ cells $/ \mathrm{ml}$ in serumfree DMEM/F12 with $10 \mathrm{ng} / \mathrm{ml}$ basic FGF and $20 \mathrm{ng} / \mathrm{ml}$ EGF together with $5 \mu \mathrm{g} / \mathrm{ml}$ insulin and $0.4 \%$ BSA. Spheres were further dissociated using nonenzymatic solution every 7-10 days to evaluate signal cell sphere formation. Gassenmaier et al. [14] obtained tumor spheres from two RCC cell lines derived from primary tumors of ccRCC patients with disease stage I (RCC-26) and stage IV (RCC-53). Tumor spheres were formed in serum-free medium consisting of DMEM/F12, 1 \% insulin-transferrin-selenium-X, $2 \%$ B27, $20 \mathrm{ng} / \mathrm{ml} \mathrm{EGF,} \mathrm{and} 20 \mathrm{ng} / \mathrm{ml}$ basic FGF. Cells were seeded in low attachment plates and grown for up to 7 days. The number of spheres was assessed after 4 days to avoid miscalculation connected with aggregates of spheres [14].

Modification of the cell culture technique to obtain $\mathrm{CD}_{105^{+}}$cells from floating tumor spheres has been demonstrated by $\mathrm{Hu}$ et al. [67]. In their method, cultures were disrupted into single cells using a $37 \mu \mathrm{m}$ filter, and cultured in 96-well plates with a low adhesion surface. The cells were added to each well at a concentration of 300-500 cells/well. Cultures were fed with serum-free medium supplemented with N2 (1:100), heparin $(5 \mathrm{~g} / \mathrm{ml})$, 
EGF and basic FGF (both $20 \mathrm{ng} / \mathrm{ml})$, insulin $(20 \mathrm{ng} / \mathrm{ml}$ ), B27 (1 \%), and human leukemia inhibitory factor (100 ng/ml) [67].

Spheres were obtained from ACHN and Caki-1 cells while culturing in SFDM supplemented with FGF, EGF, and B27. Spheres from those Caki-1 and ACHN cell lines were positive for $\mathrm{CD} 24^{+} / \mathrm{CD} 44^{+}$at $10 \%$ and $9.37 \%$, respectively [22]. In addition, spheres from both cell lines exhibited greater tumorigenic ability and increased expression for stem cell and mesenchymal markers in in-vivo studies, demonstrating capabilities of inducing self-renewal and significantly increased expression for mesenchymal markers such as ZEB1, ZEB2, vimentin, and $\mathrm{N}$-cadherin, and cancer stem markers CD24 and CD44 [22].

\section{Serum-free culture-based approach}

In 1992, Reynolds and Weiss [68] developed the sphere culture method with cells isolated from adult mammalian brain. This method has since been employed to isolate cells with CSC/TIC characteristics. Many studies confirmed that under serum-free conditions and in the presence of specific mitogens, such as EGF and basic FGF, the CSC/TIC population can be enriched [69-71]. The human RCC cell line SK-RC-42 was cultured by employing the sphere culture method for enriching CSCs/TICs [72]. Initially, SK-RC-42 cells were maintained as a monolayer in DMEM/F12 with $10 \%$ FBS. Tumor spheres were cultured by growing cells as a monolayer in serum-free DMEM/F12 with $20 \mathrm{ng} / \mathrm{ml}$ EGF, $20 \mathrm{ng} / \mathrm{ml}$ basic FGF, and B27 supplements. After 7-10 days, the tumor sphere was collected using gravity and was dissociated using $0.1 \%$ trypsin and $1 \mathrm{mM}$ EDTA. The cells were passed through $40 \mu \mathrm{m}$ nylon mesh and plated at 1000 cells/ml in serum-free DMEM/ F12 as described earlier to produce clonal spheres. These spheres were further tested for putative stem cell markers such as CD24, CD44, CD105, and CD133. However, expression of CD105 was observed in all cultures, which corresponds with the previous finding by Bussolati et al. [2] showing $\mathrm{CD}_{105^{+}}$cells as TICs. In contrast, Zhang et al. [27] used the serum-free approach to assess the tumor sphere-forming ability after artificially inducing EMT in RCC cell culture rather than enriching the stemness properties in cell culture.

\section{Conclusions}

Multiparametric flow cytometry allows simultaneous analysis of different cellular features with high performance and reliability. This method can be used to separate cells of interest using expression markers or functional properties through FACS [73]. However, isolation and analysis of tissue samples with this method can cause artifacts that bias analysis [74]. New putative CSC/TIC markers on the basis of surface expression in RCC cells are under investigation. However, the reliability of CSC/ TIC markers in cancer research is still under debate [75]. CSCs/TICs accumulated mutations in some of the key signaling pathways, such as Wnt, Notch, and Hedgehog, that are mainly responsible for proliferation, apoptosis, cell cycle, repair, and other functional features [76]. These genetic mutations trigger the tumor phenotype in normal stem cells. The cellular phenotype of CSCs/TICs is transient and may vary during the development and growth of in-vivo and in-vitro tumor culture. Phenotypic changes that occur in in-vitro experimental conditions also influence marker expression analysis and detectability [77]. It has often been observed that some marker proteins on the cell surface are sensitive to enzymatic digestion, particularly when cells need to be digested before flow cytometry analysis [78]. Optimization of culturing conditions is therefore necessary before isolation and flow cytometry analysis. The choice of protease for cell detachment is highly important for preserving the antigenicity of individual cell surface markers for the identification and sorting of CSCs/TICs [79]. An alternative to trypsin is the use of Accutase, which is often viewed as being gentler for cellular detachment without the need for a neutralizing solution.

CSCs/TICs often express $\mathrm{ABC}$ transporter proteins, which enables use of DNA dyes such as Hoechst 33342 and Rh123 and the use of flow cytometry to identify them as a "side population" [80]. When SP cells are identified though staining, it is not clear whether they represent the entire pool of CSCs in a tumor or just part of it [73]. Differences in staining protocols may contribute to such discrepancies as the cell staining incubation time, dye concentrations, cell densities, and different gating strategies [81, 82]. Cell line-specific properties also influence analysis [82]. Proper measures should therefore be taken before adjusting the staining protocol.

There are variations that exist in the Hoechst 33342 staining protocol, and these variations therefore have to be taken into consideration before interpreting data [81]. Different manufacturers offer variation in the final working concentration of Hoechst 33342 dye. Commonly, the final working concentration varies from 0.1 to $10 \mu \mathrm{g} / \mathrm{ml}$ Hoechst 33342 dye in a reaction tube. The correlation between the incubation time and the Hoechst dye concentration is crucial for dye uptake kinetics in characterizing CSCs [83]. These variations in protocol probably lead to skepticism and uncertainty about the accuracy of the Hoechst method for stem cell detection [73].

Analysis of stem cell features though the SP, ALDH, or cell surface markers exclusively have limitations to identify CSCs/TICs in RCC. For instance, Bussolati et al. [2] analyzed the cell surface marker CD105 alone as CSCs/ TICs in RCC tissues. On the other hand, SP analysis 
alone was sufficient to identify CSC/TIC phenotypes in the RCC cell line 769-P [47]. Combining several markers is therefore suggested. A combination of SP or ALDH analysis with cell surface markers such as CD105, CD133, or CXCR4 in investigating CSCs/TICs in RCC will provide significant and valuable data in the future.

\begin{abstract}
Abbreviations
7-AAD: 7-Aminoactinomycin D; ABC: ATP-binding cassette; ALDH: Aldehyde dehydrogenase; BSA: Bovine serum albumin; ccRCC: Clear cell renal cell carcinoma; CSC: Cancer stem cell; DCV: Dye-cycle violet; DMEM: Dulbecco's modified Eagle's medium; EDTA: Ethylenediamine tetraacetic acid; EGF: Epidermal growth factor; EMT: Epithelial-mesenchymal transition; FACS: Fluorescence-activated cell sorting; FBS: Fetal bovine serum; FGF: Fibroblast growth factor; FTC: Fumitremorgin C; HSP: Heat shock protein; MACS: Magnetic-activated cell sorting; MEM: Minimum essential medium; miRNA: Micro RNA; MSC: Mesenchymal stem cell; NCS: Neonatal calf serum; PBS: Phosphate-buffered saline; PI: Propidium iodide; RCC: Renal cell carcinoma; Rh123: Rhodamine 123; SFDM: Serum-free defined media; siRNA: Small interfering RNA; SP: Side population; SR-FTIR: Synchrotron radiation-Fourier transform infrared; tAPC: Tubular adult renal progenitor cell; TCGA KIRC: The Cancer Genome Atlas' Kidney Renal Clear Cell Carcinoma; TGF: Transforming growth factor; TIC: Tumor initiating cell.
\end{abstract}

\section{Competing interests}

The authors declare that they have no competing interests.

\section{Acknowledgements}

This work was supported by the National Centre for Research and Development (NCBR, Poland) "LIDER" grant number Lider/031/625/L-4/NCBR/2013.

\section{Author details}

${ }^{1}$ Molecular Oncology Laboratory, Clinic of Oncology, Military Institute of Medicine, ul. Szaserów 128, 04-141 Warsaw, Poland. ${ }^{2}$ Institute of Genetics and Biotechnology, Faculty of Biology, University of Warsaw, 02-106 Warsaw, Poland. ${ }^{3}$ Institute of Biochemistry and Biophysics, Polish Academy of Sciences, 02-106 Warsaw, Poland. ${ }^{4}$ Department of Urology, Emory University School of Medicine, Atlanta, GA 30322, USA.

\section{Published online: 16 September 2015}

\section{References}

1. Duff SE, Li C, Garland JM, Kumar S. CD105 is important for angiogenesis: evidence and potential applications. FASEB J. 2003;17:984-92.

2. Bussolati B, Bruno S, Grange C, Ferrando U, Camussi G. Identification of a tumor-initiating stem cell population in human renal carcinomas. FASEB J. 2008;22:3696-705.

3. Khan MI, Czarnecka AM, Szczylik C. Detection of CD105+ and CD133+ subpopulations (cancer initiating cells) in SMKT-R2, SMKT-R3 and 786-O human primary renal cancer cell lines [Abstract]. In: Wiersdorff $V$, editor. The 4th EMBO meeting; September 22-25, 2012. France.: Nice; 2012. p. 212-3.

4. Khan MI, Czarnecka AM, Krol M, Zdanowski R, Sobocinska A, Lewicki S, et al. Analysis of tumor initiating cells (TICS) populations in primary and metastatic cell lines from clear cell renal cell carcinoma (ccRCC) [Abstract]. Mumbai: 4th International Conference on Stem Cells and Cancer (ICSCC-2013); 2013 October 19-22; 2013. p. 73-4.

5. Li Z. CD133: a stem cell biomarker and beyond. Exp Hematol Oncol. 2013;2:17.

6. You H, Ding W, Rountree CB. Epigenetic regulation of cancer stem cell marker CD133 by transforming growth factor-beta. Hepatology. 2010;51:1635-44.

7. Bussolati B, Bruno S, Grange C, Buttiglieri S, Deregibus MC, Cantino D, et al Isolation of renal progenitor cells from adult human kidney. Am J Pathol. 2005;166:545-55

8. Bruno S, Bussolati B, Grange C, Collino F, Graziano ME, Ferrando U, et al. CD133+ renal progenitor cells contribute to tumor angiogenesis. Am J Pathol. 2006;169:2223-35.

9. Galleggiante V, Rutigliano M, Sallustio F, Ribatti D, Ditonno P, Bettocchi C, et al. CTR2 identifies a population of cancer cells with stem-like features in patients with clear cell renal cell carcinoma. J Urol. 2014;192:1831-41. doi:10.1016/j.juro.2014.06.070.

10. Lapidot T, Kollet O. The essential roles of the chemokine SDF-1 and its receptor CXCR4 in human stem cell homing and repopulation of transplanted immune-deficient NOD/SCID and NOD/SCID/B2m(null) mice. Leukemia. 2002;16:1992-2003.

11. Kucia M, Reca R, Miekus K, Wanzeck J, Wojakowski W, Janowska-Wieczorek A, et al. Trafficking of normal stem cells and metastasis of cancer stem cells involve similar mechanisms: pivotal role of the SDF-1-CXCR4 axis. Stem Cells. 2005;23:879-94.

12. Mukherjee D, Zhao J. The Role of chemokine receptor CXCR4 in breast cancer metastasis. Am J Cancer Res. 2013;3:46-57.

13. Schrader AJ, Lechner O, Templin M, Dittmar KE, Machtens S, Mengel M, et al. CXCR4/CXCL12 expression and signalling in kidney cancer. Br J Cancer. 2002:86:1250-6.

14. Gassenmaier M, Chen D, Buchner A, Henkel L, Schiemann M, Mack B, et al. CXC chemokine receptor 4 is essential for maintenance of renal cell carcinoma-initiating cells and predicts metastasis. Stem Cells. 2013;31:1467-76.

15. Ponta H, Sherman L, Herrlich PA. CD44: from adhesion molecules to signalling regulators. Nat Rev Mol Cell Biol. 2003;4:33-45.

16. Hiraga $\mathrm{T}$, Ito $\mathrm{S}$, Nakamura $\mathrm{H}$. Cancer stem-like cell marker CD44 promotes bone metastases by enhancing tumorigenicity, cell motility, and hyaluronan production. Cancer Res. 2013;73:4112-22.

17. Mahalingaiah PK, Ponnusamy L, Singh KP. Chronic oxidative stress leads to malignant transformation along with acquisition of stem cell characteristics, and epithelial to mesenchymal transition in human renal epithelial cells. J Cell Physiol. 2015;230:1916-28.

18. Visvader JE, Lindeman GJ. Cancer stem cells in solid tumours: accumulating evidence and unresolved questions. Nat Rev Cancer. 2008;8:755-68.

19. Toole BP. Hyaluronan-CD44 interactions in cancer: paradoxes and possibilities. Clin Cancer Res. 2009;15:7462-8.

20. Debeb BG, Zhang X, Krishnamurthy S, Gao H, Cohen E, Li L, et al. Characterizing cancer cells with cancer stem cell-like features in $293 \mathrm{~T}$ human embryonic kidney cells. Mol Cancer. 2010;9:180.

21. Lu J, Cui Y, Zhu J, He J, Zhou G, Yue Z. Biological characteristics of Rh123 stem-like cells in a side population of 786-O renal carcinoma cells. Oncol Lett. 2013:5:1903-8.

22. Lichner Z, Saleh C, Subramaniam V, Seivwright A, Prud'homme GJ, Yousef GM. miR-17 inhibition enhances the formation of kidney cancer spheres with stem cell/ tumor initiating cell properties. Oncotarget. 2014;6:5567-81.

23. Nishizawa S, Hirohashi Y, Torigoe T, Takahashi A, Tamura Y, Mori T, et al. HSP DNAJB8 controls tumor-initiating ability in renal cancer stem-like cells. Cancer Res. 2012;72:2844-54.

24. Morita R, Nishizawa S, Torigoe T, Takahashi A, Tamura Y, Tsukahara T, et al. Heat shock protein DNAJB8 is a novel target for immunotherapy of colon cancer-initiating cells. Cancer Sci. 2014;105:389-95.

25. Melton C, Judson RL, Blelloch R. Opposing microRNA families regulate self-renewal in mouse embryonic stem cells. Nature. 2010:463:621-6.

26. Liu C, Tang DG. MicroRNA regulation of cancer stem cells. Cancer Res. 2011;71:5950-4

27. Zhang L, Jiao M, Wu K, Li L, Zhu G, Wang X, et al. TNF-alpha induced epithelial mesenchymal transition increases stemness properties in renal cell carcinoma cells. Int J Clin Exp Med. 2014;7:4951-8.

28. Li W, Wang Q, Su Q, Ma D, An C, Ma L, et al. Honokiol suppresses renal cancer cells' metastasis via dual-blocking epithelial-mesenchymal transition and cancer stem cell properties through modulating miR-141/ZEB2 signaling. Mol Cells. 2014;37:383-8.

29. Weygant N, Qu D, May R, Tierney RM, Berry WL, Zhao L, et al. DCLK1 is a broadly dysregulated target against epithelial-mesenchymal transition, focal adhesion, and stemness in clear cell renal carcinoma. Oncotarget. 2015;6:2193-205.

30. Lin $Y$, Yang $Z$, Xu A, Dong P, Huang Y, Liu H, et al. PIK3R1 negatively regulates the epithelial-mesenchymal transition and stem-like phenotype of renal cancer cells through the AKT/GSK3beta/CTNNB1 signaling pathway. Sci Rep. 2015:5:8997.

31. Sabet MN, Rakhshan A, Erfani E, Madjd Z. Co-expression of putative cancer stem cell markers, CD133 and Nestin, in skin tumors. Asian Pac J Cancer Prev. 2014;15:8161-9.

32. Hou YC, Chao YJ, Tung HL, Wang HC, Shan YS. Coexpression of CD44-positive/ CD133-positive cancer stem cells and CD204-positive tumor-associated 
macrophages is a predictor of survival in pancreatic ductal adenocarcinoma. Cancer. 2014;120:2766-77.

33. Buczek M, Escudier B, Bartnik E, Szczylik C, Czarnecka A. Resistance to tyrosine kinase inhibitors in clear cell renal cell carcinoma: from the patient's bed to molecular mechanisms. Biochim Biophys Acta. 1845;2014:31-41.

34. Varna M, Gapihan G, Feugeas JP, Ratajczak P, Tan S, Ferreira I, et al. Stem cells increase in numbers in perinecrotic areas in human renal cancer. Clin Cancer Res. 2015;21:916-24.

35. Semple JW, Allen D, Chang W, Castaldi P, Freedman J. Rapid separation of CD4+ and CD19+ lymphocyte populations from human peripheral blood by a magnetic activated cell sorter (MACS). Cytometry. 1993;14:955-60.

36. Schmitz J, Petrasch S, van Lunzen J, Racz P, Kleine HD, Hufert F, et al. Optimizing follicular dendritic cell isolation by discontinuous gradient centrifugation and use of the magnetic cell sorter (MACS). J Immunol Methods. 1993;159:189-96.

37. Schmitz B, Radbruch A, Kummel T, Wickenhauser C, Korb H, Hansmann ML, et al. Magnetic activated cell sorting (MACS) - a new immunomagnetic method for megakaryocytic cell isolation: comparison of different separation techniques. Eur J Haematol. 1994;52:267-75.

38. Hansel TT, De Vries IJ, Iff T, Rihs S, Wandzilak M, Betz S, et al. An improved immunomagnetic procedure for the isolation of highly purified human blood eosinophils. J Immunol Methods. 1991;145:105-10.

39. Burkert J, Otto WR, Wright NA. Side populations of gastrointestinal cancers are not enriched in stem cells. J Pathol. 2008;214:564-73.

40. Takaishi S, Okumura T, Tu S, Wang SS, Shibata W, Vigneshwaran R, et al. Identification of gastric cancer stem cells using the cell surface marker CD44. Stem Cells. 2009:27:1006-20.

41. Broadley KW, Hunn MK, Farrand KJ, Price KM, Grasso C, Miller RJ, et al. Side population is not necessary or sufficient for a cancer stem cell phenotype in glioblastoma multiforme. Stem Cells. 2011;29:452-61.

42. Golebiewska A, Brons NH, Bjerkvig R, Niclou SP. Critical appraisal of the side population assay in stem cell and cancer stem cell research. Cell Stem Cell. 2011;8:136-47.

43. Goodell MA, Brose K, Paradis G, Conner AS, Mulligan RC. Isolation and functional properties of murine hematopoietic stem cells that are replicating in vivo. J Exp Med. 1996;183:1797-806.

44. Addla SK, Brown MD, Hart CA, Ramani VA, Clarke NW. Characterization of the Hoechst 33342 side population from normal and malignant human renal epithelial cells. Am J Physiol Renal Physiol. 2008;295:F680-7.

45. Ueda K, Ogasawara S, Akiba J, Nakayama M, Todoroki K, Sanada S, et al. Aldehyde dehydrogenase 1 identifies cells with cancer stem cell-like properties in a human renal cell carcinoma cell line. PloS One. 2013:8:e75463.

46. Matthew L, Thomas T, Hart C. The renal cell carcinoma side population: the potential use of targeted agents as novel MDR modulators to circumvent chemoresistance. J Urol. 2011;85:e94.

47. Huang B, Huang YJ, Yao ZJ, Chen X, Guo SJ, Mao XP, et al. Cancer stem cell-like side population cells in clear cell renal cell carcinoma cell line 769P. PloS One. 2013:8:e68293.

48. Hughes C, Liew M, Sachdeva A, Bassan P, Dumas P, Hart CA, et al. SR-FTIR spectroscopy of renal epithelial carcinoma side population cells displaying stem cell-like characteristics. Analyst. 2010;135:3133-41.

49. Khan MI, Czarnecka AM, Duchnowska R, Kukwa W, Szczylik C. Metastasis-initiating cells in renal cancer. Curr Signal Transduct Ther. 2014:8:240-6.

50. Dean M, Fojo T, Bates S. Tumour stem cells and drug resistance. Nat Rev Cancer. 2005:5:275-84

51. Bunting $K D$. ABC transporters as phenotypic markers and functional regulators of stem cells. Stem Cells. 2002;20:11-20.

52. Palmeira CM, Moreno AJ, Madeira VM, Wallace KB. Continuous monitoring of mitochondrial membrane potential in hepatocyte cell suspensions. J Pharmacol Toxicol Methods. 1996;35:35-43.

53. Keith B, Simon MC. Hypoxia-inducible factors, stem cells, and cancer. Cell. 2007;129:465-72.

54. Prince ME, Sivanandan R, Kaczorowski A, Wolf GT, Kaplan MJ, Dalerba P, et al. Identification of a subpopulation of cells with cancer stem cell properties in head and neck squamous cell carcinoma. Proc Natl Acad Sci U S A. 2007;104:973-8.

55. She JJ, Zhang PG, Wang ZM, Gan WM, Che XM. Identification of side population cells from bladder cancer cells by DyeCycle Violet staining. Cancer Biol Ther. 2008;7:1663-8.
56. Gangavarpu KJ, Huss WJ. Isolation and applications of prostate side population cells based on dye cycle violet efflux. Curr Protoc Toxicol. 2011; Chapter 22:Unit 22.2.

57. Mathew G, Timm Jr EA, Sotomayor P, Godoy A, Montecinos VP, Smith GJ, et al. ABCG2-mediated DyeCycle Violet efflux defined side population in benign and malignant prostate. Cell Cycle. 2009;8:1053-61.

58. Ma S, Chan KW, Lee TK, Tang KH, Wo JY, Zheng BJ, et al. Aldehyde dehydrogenase discriminates the CD133 liver cancer stem cell populations. Mol Cancer Res. 2008;6:1146-53.

59. Jiang F, Qiu Q, Khanna A, Todd NW, Deepak J, Xing L, et al. Aldehyde dehydrogenase 1 is a tumor stem cell-associated marker in lung cancer. Mol Cancer Res. 2009;7:330-8.

60. Kim MP, Fleming JB, Wang H, Abbruzzese JL, Choi W, Kopetz S, et al. ALDH activity selectively defines an enhanced tumor-initiating cell population relative to CD133 expression in human pancreatic adenocarcinoma. PloS One. 2011;6:e20636.

61. van den Hoogen C, van der Horst G, Cheung H, Buijs JT, Lippitt JM, Guzman-Ramirez N, et al. High aldehyde dehydrogenase activity identifies tumor-initiating and metastasis-initiating cells in human prostate cancer. Cancer Res. 2010;70:5163-73.

62. Kuroda T, Hirohashi Y, Torigoe T, Yasuda K, Takahashi A, Asanuma H, et al. ALDH1-high ovarian cancer stem-like cells can be isolated from serous and clear cell adenocarcinoma cells, and ALDH1 high expression is associated with poor prognosis. PloS One. 2013;8:e65158.

63. Wang L, Park P, La Marca F, Than KD, Lin CY. BMP-2 inhibits tumor-initiating ability in human renal cancer stem cells and induces bone formation. J Cancer Res Clin Oncol. 2015;141:1013-24. doi:10.1007/s00432-014-1883-0.

64. Fischbach C, Chen R, Matsumoto T, Schmelzle T, Brugge JS, Polverini PJ, et al. Engineering tumors with 3D scaffolds. Nat Methods. 2007;4:855-60.

65. Jain K, Yang H, Cai BR, Haque B, Hurvitz Al, Diehl C, et al. Retrievable, replaceable, macroencapsulated pancreatic islet xenografts. Long-term engraftment without immunosuppression. Transplantation. 1995;59:319-24.

66. Smith BH, Gazda LS, Conn BL, Jain K, Asina S, Levine DM, et al. Threedimensional culture of mouse renal carcinoma cells in agarose macrobeads selects for a subpopulation of cells with cancer stem cell or cancer progenitor properties. Cancer Res. 2011;71:716-24.

67. Hu D, Wang X, Mao Y, Zhou L. Identification of CD105 (endoglin)-positive stem-like cells in rhabdoid meningioma. J Neuro-Oncol. 2012;106:505-17.

68. Reynolds BA, Weiss S. Generation of neurons and astrocytes from isolated cells of the adult mammalian central nervous system. Science. 1992:255:1707-10.

69. Singh SK, Clarke ID, Terasaki M, Bonn VE, Hawkins C, Squire J, et al. Identification of a cancer stem cell in human brain tumors. Cancer Res. 2003:63:5821-8.

70. Cariati M, Naderi A, Brown JP, Smalley MJ, Pinder SE, Caldas C, et al. Alpha-6 integrin is necessary for the tumourigenicity of a stem cell-like subpopulation within the MCF7 breast cancer cell line. Int J Cancer. 2008;122:298-304.

71. Eramo A, Lotti F, Sette G, Pilozzi E, Biffoni M, Di Virgilio A, et al. Identification and expansion of the tumorigenic lung cancer stem cell population. Cell Death Diff. 2008;15:504-14.

72. Zhong Y, Guan K, Guo S, Zhou C, Wang D, Ma W, et al. Spheres derived from the human SK-RC-42 renal cell carcinoma cell line are enriched in cancer stem cells. Cancer Lett. 2010;299:150-60.

73. Greve B, Kelsch R, Spaniol K, Eich HT, Gotte M. Flow cytometry in cancer stem cell analysis and separation. Cytometry A. 2012;81:284-93.

74. Panchision DM, Chen HL, Pistollato F, Papini D, Ni HT, Hawley TS. Optimized flow cytometric analysis of central nervous system tissue reveals novel functional relationships among cells expressing CD133, CD15, and CD24. Stem Cells. 2007;25:1560-70.

75. Fabian A, Barok M, Vereb G, Szollosi J. Die hard: are cancer stem cells the Bruce Willises of tumor biology? Cytometry A. 2009;75:67-74.

76. Vogelstein B, Kinzler KW. Cancer genes and the pathways they control. Nat Med. 2004;10:789-99.

77. Pallini $\mathrm{R}$, Casalbore $\mathrm{P}$, Mercanti D, Maggiano N, Larocca LM Phenotypic change of human cultured meningioma cells. J Neuro-Oncol. 2000;49:9-17.

78. Wang Y, Krivtsov AV, Sinha AU, North TE, Goessling W, Feng Z, et al. The Wnt/beta-catenin pathway is required for the development of leukemia stem cells in AML. Science. 2010;327:1650-3. 
79. Stingl J, Eirew P, Ricketson I, Shackleton M, Vaillant F, Choi D, et al.

Purification and unique properties of mammary epithelial stem cells. Nature. 2006;439:993-7.

80. Hiraga T, Ito S, Nakamura H. Side population in MDA-MB-231 human breast cancer cells exhibits cancer stem cell-like properties without higher bone-metastatic potential. Oncol Rep. 2011;25:289-96.

81. Srivastava VK, Nalbantoglu J. Flow cytometric characterization of the DAOY medulloblastoma cell line for the cancer stem-like phenotype. Cytometry A. 2008; $73: 940-8$

82. Wu C, Alman BA. Side population cells in human cancers. Cancer Lett. 2008:268:1-9.

83. Ibrahim SF, Diercks AH, Petersen TW, van den Engh G. Kinetic analyses as a critical parameter in defining the side population (SP) phenotype. Exp Cell Res. 2007;313:1921-6.

84. Gazda LS, Martis PC, Laramore MA, Bautista MA, Dudley A, Vinerean HV, et al. Treatment of agarose-agarose RENCA macrobeads with docetaxel selects for OCT4(+) cells with tumor-initiating capability. Cancer Biol Ther. 2013;14:1147-57. 